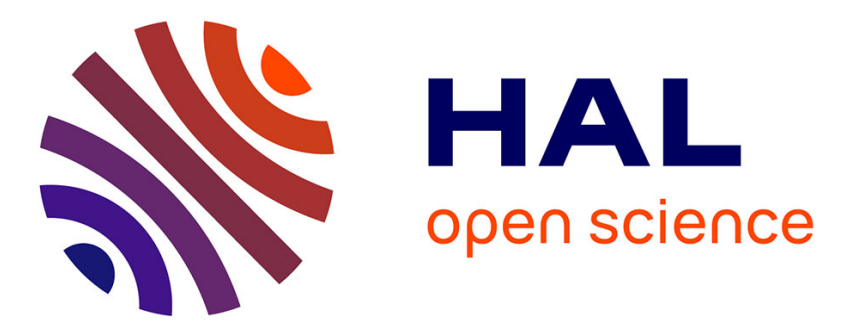

\title{
Reactivity enhancement of gasification biochars for catalytic applications
}

Marion Ducousso, Elsa Weiss-Hortala, Ange Nzihou, Marco J. Castaldi

\section{To cite this version:}

Marion Ducousso, Elsa Weiss-Hortala, Ange Nzihou, Marco J. Castaldi. Reactivity enhancement of gasification biochars for catalytic applications. Fuel, 2015, 159, p. 491-499. 10.1016/j.fuel.2015.06.100 . hal-01609221

\section{HAL Id: hal-01609221 https://hal.science/hal-01609221}

Submitted on 4 May 2018

HAL is a multi-disciplinary open access archive for the deposit and dissemination of scientific research documents, whether they are published or not. The documents may come from teaching and research institutions in France or abroad, or from public or private research centers.
L'archive ouverte pluridisciplinaire HAL, est destinée au dépôt et à la diffusion de documents scientifiques de niveau recherche, publiés ou non, émanant des établissements d'enseignement et de recherche français ou étrangers, des laboratoires publics ou privés. 


\title{
Reactivity enhancement of gasification biochars for catalytic applications
}

\author{
Marion Ducousso $^{\mathrm{a}, *}$, Elsa Weiss-Hortala ${ }^{\mathrm{a}}$, Ange Nzihou ${ }^{\mathrm{a}}$, Marco J. Castaldi ${ }^{\mathrm{b}}$ \\ ${ }^{a}$ Université de Toulouse, Mines Albi, CNRS, Centre RAPSODEE, Albi, France \\ ${ }^{\mathrm{b}}$ Chemical Engineering Department, City College, City University of New York, New York City, USA
}

\section{H I G H L I G H T S}

- $\mathrm{O}_{2}$ gas-phase treatment on biochars has been efficient.

- $\mathrm{O}_{2}$ gas-phase treatment on biochars has been selective toward weak acids.

- The higher the temperature, the higher the oxygenation of the biochars surface.

- Specific surface area and porosity were significantly enhanced at 340 and $400{ }^{\circ} \mathrm{C}$.

Catalyst

Oxygenated functions

Reactivity

Selectivity

\section{A B S T R A C T}

To enhance the catalytic properties of woody biochars, an $\mathrm{O}_{2}$ gas-phase treatment was performed at different temperatures $\left(280,340\right.$ and $\left.400{ }^{\circ} \mathrm{C}\right)$ and times $(2 \mathrm{~h}, 4 \mathrm{~h}, 8 \mathrm{~h}, 16 \mathrm{~h})$ post-gasification. In fact the development of o-containing carbons based materials to increase their reactivity is gaining momentum. The efficacy and selectivity of the oxygen chemisorption on the biochars surface were investigated. FTIR revealed that the oxygenation has been efficient. Temperature Programmed Desorption (TPD) confirmed FTIR results and led to go further by providing quantitative results and insights into the selectivity. In fact the oxygen content at the surface was increased 1.3, 1.7 and 2.1 times after $2 \mathrm{~h}$ at 280,340 and $400{ }^{\circ} \mathrm{C}$ respectively. At $280^{\circ} \mathrm{C}$, above $4 \mathrm{~h}$ of treatment the surface became saturated and the oxygen content was increased by $40 \%$. The formation of weak acid functional groups has been enhanced without removing the basic functional groups already present on the surface. Carboxylic acids (strongest acids) were removed since they were not stable at the treatment temperature. The higher the total amount of o-containing functions, the more acid the $\mathrm{pH}_{\mathrm{pzc}}$. The $\mathrm{pH}_{\mathrm{pzc}}$ of the raw biochars is of 3.1. At $280^{\circ} \mathrm{C}$ even if the oxygenation was efficient it did not impact the global surface acidity. At highest temperature the higher amount of oxygenated functions decreased the $\mathrm{pH}_{\mathrm{pzc}}$ to reach and go below 2. Thus the chemisorption was efficient and selective. BET analyses showed that at highest temperatures (340 and $400{ }^{\circ} \mathrm{C}$ ) the treatment increased the surface area and porosity. At $400^{\circ} \mathrm{C}$ the specific surface area gained $15 \%$ and the porosity was increased 1.5 times whereas at $280^{\circ} \mathrm{C}$ the specific surface area decreased to reach $80 \%$ of the initial surface area. These results highlight that the combustion has been enhanced at 340 and $400{ }^{\circ} \mathrm{C}$ which burnt carbon atoms and free the pores. Thus oxygenation at 340 or $400{ }^{\circ} \mathrm{C}$ is more interesting than at $280^{\circ} \mathrm{C}$ since results have shown that the higher efficiency, specific surface area and porosity have been obtained under those conditions.

\section{Introduction}

Carbon materials have interesting surface properties to be used as adsorbents [1,2] catalysts [3] or catalytic supports [4,5]. Among the physico-chemical properties, surface oxygenated functional

\footnotetext{
* Corresponding author at: RAPSODEE (office 0E012), Ecole des Mines d'Albi-Carmaux, Campus Jarlard, 81013 Albi, France. Tel.: +33 563493240 .

E-mail addresses: marion.ducousso@mines-albi.fr (M. Ducousso), elsa.weiss@ mines-albi.fr (E. Weiss-Hortala), ange.nzihou@mines-albi.fr (A. Nzihou), mcastaldi@che.ccny.cuny.edu (M.J. Castaldi).
}

groups have been recognized to influence performance. The development of O-containing carbon based materials is of great interest and is currently utilized in many catalytic applications such as electrode materials in supercapacitors [6], reduction of tetracycline and aromatic nitro compounds $[7,8] \mathrm{SO}_{2}$ and $\mathrm{NO}_{x}$ removal from flue gases [9] and dehydrogenation/dehydration of aliphatic alcohols. For example, Szymanski et al. concluded that acidic organic functions were active sites for hydrocarbon dehydrogenation and dehydration [10-13]. In addition, Teng et al. [9] have correlated the increase of the carbon material activity toward the reduction 
Table 1

Properties of the raw biochar (proximate and ultimate analyses).

\begin{tabular}{ll}
\hline Proximate analysis & \\
Moisture content (wt\%) & 6.2 \\
Ash content (wt\%) & 3.6 \\
Ultimate analysis & \\
Element (wt\%) & \\
C & 77.4 \\
H & 2.0 \\
N & 0.5 \\
S & 0 \\
O (by difference) & 16.5 \\
\hline * $\% \mathrm{O}=100-\% \mathrm{C}-\% \mathrm{H}-\% \mathrm{~N}-\% \mathrm{~S}-\% \mathrm{ash})$. &
\end{tabular}

of $\mathrm{NO}$ with $\mathrm{NH}_{3}$ to the enhancement of acidic functions, specifically the hydroxyl type groups. Therefore functionalization of solid surfaces with $\mathrm{O}$-containing groups is of great interest to increase their reactivity.

Most of the studies about functionalization have been already performed on activated carbons from polymers sources, carbon black or coal chars which all come from fossil fuel feedstocks $[14,15]$. An emergent inexpensive candidate is biochar from biomass gasification. Typically considered as a residue, their physico-chemical properties can have application in the catalytic field $[16,17]$. Biochars are microporous material with a high surface area containing heterogeneous atoms such as metal or oxygen atoms imbedded in the carbon matrix. Different O-containing groups such as carboxylic acids, lactones, carbonyls, ethers or phenols structure have been identified on chars from biomass conversion [18]. Functionalization of their surface by increasing the oxygen content is an opportunity to further develop them as an inexpensive catalyst from renewable sources. Various methods of oxygenation have been investigated either in gas and liquid phase: such as nitric acid, phosphoric acid, hydrogen peroxide, nitrous oxide and ozone [18-20]. Liquid phase treatments are strong oxidizing agents however they tend to decrease the porosity significantly and therefore the surface area. Alternatively gas-phase treatments are known to enhance the porosity and are competitive toward oxygen chemisorption compare to liquid treatment [21].

In this study biochars from gasification of poplar wood have been oxygenated by an $\mathrm{O}_{2}$ gas-phase treatment at various temperatures ranging from $280^{\circ} \mathrm{C}$ to $400^{\circ} \mathrm{C}$ and for several duration times between $2 \mathrm{~h}$ and $16 \mathrm{~h}$. The aim of the process was to chemisorb oxygen at the surface to increase the oxygen content. However, during the $\mathrm{O}_{2}$ gas-phase treatment at the mid-range temperature, some oxygen atoms react with the carbon matrix instead of chemisorb which is traduced by a mass loss. Thus the oxygen chemisorption is in competition with the combustion reaction. At the appropriate operating conditions, the combination of these two reactions has a positive effect on the char surface properties. The chemisorption increases the oxygen content while the moderate combustion enhances the porosity and the specific surface area thus counteracting any surface area reduction associated with the chemisorption. Oxygenation of solid surfaces has already been studied using model structures such as activated carbon or black carbon. Therefore the goal of this study is to evaluate the efficacy and selectivity of the oxygen chemisorption on raw biochars. This material has already shown catalytic activity for hydrocarbon cracking or tar reforming. Its high surface area, the defects in the carbon matrix and the inherent heterogeneity (oxygenated functions and mineral content) should play a role in its reactivity. Increasing the oxygenated content is an opportunity to enhance its catalytic activity for the reactions presented in the first paragraph. Moreover the development of oxygenated biochars as catalyst is a competitive alternative to the commercial metal doped catalysts. In addition this study discusses the competition between the oxygenation and the combustion reactions for the different operating conditions (time and temperature). Firstly the oxygenation efficacy will be observed by FTIR and then its selectivity will be described using Temperature Program Desorption. In a second step the global acidity of the biochars surface is investigated and correlated to the total oxygen amount of the surface by measuring their $\mathrm{pH}_{\mathrm{pzc}}$. Finally, the evolution of the porosity and the specific surface area are investigated and linked to the mass loss to evaluate the competition between oxygen chemisorption and combustion. The final goal is to determine the best conditions to obtain the greatest level of oxygenated functions at the char surface without porosity loss in order to increase the catalytic reactivity of biochars.

\section{Experimental}

The experiments were carried out in three main steps: first poplar wood has been gasified under steam in a fluidized bed. Afterwards, the raw biochars where harvested and then oxygenated under a mixture of $8 \mathrm{v} \% \mathrm{O}_{2} / 92 \mathrm{v} \% \mathrm{~N}_{2}$ for different operating conditions and finally the oxygenated biochars surface have been characterized by Temperature Program Desorption, FTIR, $\mathrm{pH}_{\mathrm{pzc}}$ and BET analyzer.

\subsection{Raw char generation by gasification of poplar wood}

$65 \mathrm{~g}$ of poplar wood chips (furnished by Lithaspen company) have been gasified into a fluidized bed (custom-made stainless steel) at $750{ }^{\circ} \mathrm{C}$ during $30 \mathrm{~min}$ into a $90 \mathrm{v} \% \mathrm{H}_{2} \mathrm{O} / 10 \mathrm{v} \% \mathrm{~N}_{2}$ mixture (purity: 99.5\%) atmosphere of $1.5 \mathrm{Nm}^{3} / \mathrm{h}$. Prior to gasification, the poplar wood has been ground into chips of about $4 \mathrm{~mm} \times 4 \mathrm{~mm} \times 1 \mathrm{~mm}$. The gasifier was $60 \mathrm{~cm}$ height with an internal diameter of $6 \mathrm{~cm}$. A quartz frit was positioned at approximately $12 \mathrm{~cm}$ from the bottom to hold the biomass. To ensure the biomass remains in the reactor a second frit was put at the top of the reactor. Ten K-type thermocouples (IEC- KX-1) have been installed $5 \mathrm{~cm}$ apart throughout the vertical direction to measure the temperature profile. A thermocouple positioned at center height of $30 \mathrm{~cm}$ was connected to a temperature controller (IEC$\mathrm{KX}-1$ ). The heating rate was $20^{\circ} \mathrm{C} / \mathrm{min}$. Steam was produced from a vapor generator (liquid brooks mass flow controller flowomega) and nitrogen (ultra high purity) flow rate was controlled by a mass flow controller (Brooks 3851S). Post-testing, gasification chars have been crushed and sieved to obtain particle diameter between 100 and $500 \mu \mathrm{m}$. Table 1 shows the elemental composition, the ash and moisture content of the raw biochar harvested from the gasifer.

\subsection{Oxygenation of the biochars surface by $\mathrm{O}_{2} / \mathrm{N}_{2}$ gas-phase treatment}

Approximately $100 \mathrm{mg}$ of char (named raw_char) have been oxygenated in flow through micro-reactor (ChemBet Pulsar-model 05090) under a mixture of $8 \mathrm{v} \% \mathrm{O}_{2} / 92 \mathrm{v} \% \mathrm{~N}_{2}$ (ultra high purity) and a flow rate of $45 \mathrm{ml} / \mathrm{min}$ for various time durations $\left(2 \mathrm{~h}, 4 \mathrm{~h}, 8 \mathrm{~h}\right.$ and $16 \mathrm{~h}$ ) at $280^{\circ} \mathrm{C}$. The choice of oxygen concentration was to enable better resolution of the time dependence of oxygen interaction.

The produced chars utilized in this study are named as follows: ox $2 \mathrm{~h} \_280 \mathrm{C}$, ox4h_280C, ox8h_280C and ox16h_280C respectively. Oxygenation has also been carried out at $340{ }^{\circ} \mathrm{C}$ and $400{ }^{\circ} \mathrm{C}$ for $2 \mathrm{~h}$ to serve as comparisons. These chars are called: ox $2 \mathrm{~h} \_340 \mathrm{C}$ and ox2h_400C (see Table 2).

Oxygenation has been performed in a quartz U-tube with an internal diameter of $4 \mathrm{~mm}$ placed into an electrical furnace (Chembet Pulsar instrument). The char bed of $75 \mathrm{~mm}$ length was 
Table 2

Designation of the biochars.

\begin{tabular}{|c|c|c|c|c|}
\hline \# & Description & $\begin{array}{l}\text { Temp of } \\
\text { oxygenation }\left({ }^{\circ} \mathrm{C}\right)\end{array}$ & $\begin{array}{l}\text { Oxygenation } \\
\text { time }(\mathrm{h})\end{array}$ & $\begin{array}{l}\text { Name of the } \\
\text { sample }\end{array}$ \\
\hline 1 & raw char & _- & - & raw_char \\
\hline 2 & $\begin{array}{l}\mathrm{n}^{\circ} 1 \\
\text { oxygenated }\end{array}$ & 280 & 2 & ox $2 \mathrm{~h} \_280 \mathrm{C}$ \\
\hline 3 & $\begin{array}{l}\mathrm{n}^{\circ} 1 \\
\text { oxygenated }\end{array}$ & 280 & 4 & ox $4 \mathrm{~h} \_280 \mathrm{C}$ \\
\hline 4 & $\begin{array}{l}\mathrm{n}^{\circ} 1 \\
\text { oxygenated }\end{array}$ & 280 & 8 & ox8h_280C \\
\hline 5 & $\begin{array}{l}\mathrm{n}^{\circ} 1 \\
\text { oxygenated }\end{array}$ & 280 & 16 & ox16h_280C \\
\hline 6 & $\begin{array}{l}\mathrm{n}^{\circ} 1 \\
\text { oxygenated }\end{array}$ & 340 & 2 & ox $2 \mathrm{~h} \_340 \mathrm{C}$ \\
\hline 7 & $\begin{array}{l}\mathrm{n}^{\circ} 1 \\
\text { oxygenated }\end{array}$ & 400 & 2 & ox $2 \mathrm{~h} \_400 \mathrm{C}$ \\
\hline
\end{tabular}

maintained by quartz wool at the extremities. The Chembet furnace was equipped with two grounded thermocouples (K-type) one for control and the other one inserted into one branch of the U-tube to monitor for over temperature conditions. The biochar bed was heated to the oxygenation temperature under pure nitrogen with a heating rate of $5{ }^{\circ} \mathrm{C} / \mathrm{min}$. Once the oxygenation temperature was reached, the pure nitrogen (3.7 ultra high purity) was replaced by the $8 \mathrm{v} \% \mathrm{O}_{2} / 92 \mathrm{v} \% \mathrm{~N}_{2}$ mixture after twenty minutes. The oxygenation process was carried out in two steps because $\mathrm{CO}_{2}$ was produced all over the process but was not coming from the same origin. During the heating $\mathrm{CO}_{2}$ was produced due to the desorption of carboxylic acids which were not stable at the oxygenation temperature. Then, during the oxygenation, combustion produces $\mathrm{CO}_{2}$. To be able to differentiate the $\mathrm{CO}_{2}$ production origin, the heating was performed under pure nitrogen. Once the $\mathrm{CO}_{2}$ production was almost equal to zero, the $8 \mathrm{v} \% \mathrm{O}_{2} / 92 \mathrm{v} \% \mathrm{~N}_{2}$ mixture was introduced. The effluent gas phase was analyzed online using a gas chromatograph (Agilent 3000A) with four different columns and TCD detectors which allow the detection of $\mathrm{He}, \mathrm{N}_{2}, \mathrm{O}_{2}, \mathrm{H}_{2}$, $\mathrm{CH}_{4}, \mathrm{CO}$ and $\mathrm{CO}_{2}$. Production of $\mathrm{CO}_{2}$ and $\mathrm{CO}$ was observed during the process which means combustion occurs during the oxygenation. The mass loss during the oxygenation process has been calculated from the following equation:

$M L=\frac{\left(m_{i}-m_{f}\right)}{m_{i}}$

where $m_{i}$ is the initial mass of the biochar sample and $m_{f}$ is the final mass after the process.

\subsection{Biochars surface characterization}

The surfaces of raw and oxygenated biochars have been characterized by Temperature Program Desorption (TPD), FTIR, measure of their $\mathrm{pH}_{\mathrm{pzc}}$ and BET.

\subsubsection{Temperature Programmed Desorption (TPD)}

The Temperature Programmed Desorption (TPD) provides information about the nature and quantity of the different oxygenated groups at the surface of a solid. TPD of $50 \mathrm{mg}$ of raw and functionalized chars have been performed in the ChemBet Pulsar instrument under a $25 \mathrm{ml} / \mathrm{min}$ of helium from $25^{\circ} \mathrm{C}$ to $1100^{\circ} \mathrm{C}$ with an heating rate of $5^{\circ} \mathrm{C} / \mathrm{min}$. The same set-up as for the oxygenation was used (see Section 2.2). Gas production was monitored by both the TCD detector from the ChemBet Instrument and by a 3000a gas chromatoghraph from Agilent with four different columns and TCD detectors which allow the detection of $\mathrm{He}, \mathrm{N}_{2}, \mathrm{O}_{2}, \mathrm{H}_{2}, \mathrm{CH}_{4}, \mathrm{CO}$ and $\mathrm{CO}_{2}$. The total production of $\mathrm{CO}_{2}$ and $\mathrm{CO}$ were calculated from the integration of the area under the curve of the chromatograms. The
TCD detector provides a continuous signal but the separation of the components is not possible while the micro gas chromatograph does the differentiation but it only allows a semi-continuous analysis. Results of the micro gas chromatograph have been used for a quantitative comparison of the $\mathrm{CO}_{2}$ and $\mathrm{CO}$ production during the TPD analyses. The deconvolution of the TCD signal has been performed on the TPRWin software furnished with the ChemBet Pulsar instrument.

\subsubsection{FTIR}

FTIR spectroscopy has been performed to observe the carbonoxygen bondings at the biochars surface. Prior FTIR analyses samples have been finely ground in a mortar and mixed in $\mathrm{KBr}$. Spectra have been obtained from a Nicolet Impact 400D spectrometer by adding 32 accumulations at a resolution of $8 \mathrm{~cm}^{-1}$.

\subsection{3. $\mathrm{pH}_{\mathrm{pzc}}$}

The $\mathrm{pH}_{\mathrm{pzc}}$ of the different biochars have been performed to evaluate the global acidity of the surface. The $\mathrm{pH}$ at the point of zero charge is the $\mathrm{pH}$ above which the total surface of the carbon particle is negatively charged [22]. Prior to analysis buffer solutions fixed at $\mathrm{pH}=2, \mathrm{pH}=3.1, \mathrm{pH}=4, \mathrm{pH}=7$ and $\mathrm{pH}=10$ have been prepared and biochars have been crushed to obtain powder. $5 \mathrm{mg}$ of powder have been immersed into $5 \mathrm{~mL}$ of buffered solution. After stabilization, the value of the zeta potential has been determined using a Zetasizer Nano ZS Malvern instrument.

\subsubsection{BET}

Textural properties such as specific surface area and micropore volume could be determined by adsorption of an inert gas. BET analyses have been done on an ASAP 2010 apparatus from Micromeritics. Adsorption of argon has been monitored at $77 \mathrm{~K}$ until a relative pressure of 1 . Prior argon adsorption a degassing step of $30 \mathrm{~h}$ under high vacuum at $200^{\circ} \mathrm{C}$ has been performed. Specific surface area has been determined by application of the BET model. Pore size and pore volume have been evaluated using the Horvath-Kawazoe model.

\section{Results and discussion}

The discussion is first focused on the time dependence of the oxygenation process and afterwards the temperature effect is studied. The efficacy, selectivity, global acidity and the evolution of the porosity/specific surface area over the oxygenation are the four main points addressed in this section.

\subsection{Impact of the oxygenation time of the o-containing groups}

At $280{ }^{\circ} \mathrm{C}$ the oxygenation process has been stopped at $2 \mathrm{~h}, 4 \mathrm{~h}$, $8 \mathrm{~h}$ and $16 \mathrm{~h}$ to investigate the time dependence of the oxygen chemisorption. First, the efficacy and selectivity were evaluated by FTIR and TPD analyses. Once the total amount of oxygenated functions at the different biochars surfaces was determined it has been correlated to the global acidity of the surface by measurement of the $\mathrm{pH}_{\mathrm{pzc}}$. Finally the evolution of the specific surface area and porosity have been carried out and correlated to the mass loss values.

\subsubsection{Efficacy}

The goal of oxygen chemisorption is to increase the total $\mathrm{O}$-containing functions at the biochar surface. Its efficacy has been evaluated using two complementary techniques: FTIR and TPD. FTIR spectroscopy is sensitive to the different carbon-oxygen bondings. Fig. 1 shows the $800-2000 \mathrm{~cm}^{-1}$ region of FTIR spectra for the raw and functionalized biochars. All the spectra show bands in the 


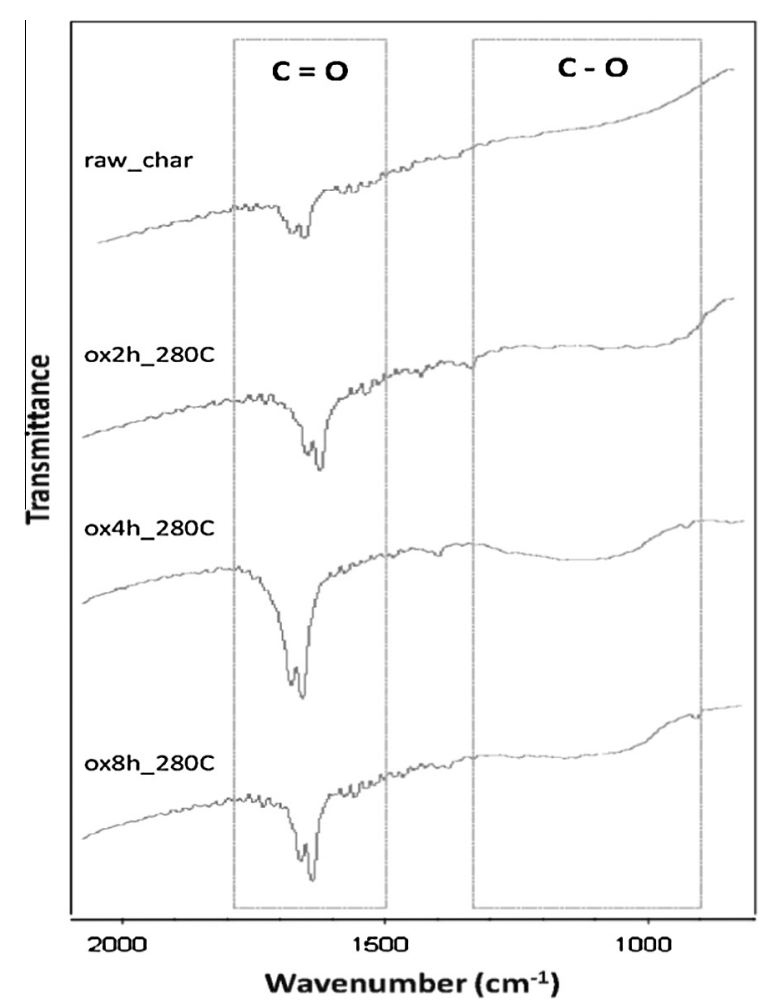

Fig. 1. Comparison of the $1000-2000 \mathrm{~cm}^{-1}$ region of FTIR spectra of raw and oxygenated biochars at $280^{\circ} \mathrm{C}$.

region $1600-1800 \mathrm{~cm}^{-1}$ corresponding to the $\mathrm{C}=\mathrm{O}$ bonds associated with anhydrides, lactones, carboxylic and quinones (see Table 3). Profiles of the functionalized char at $280^{\circ} \mathrm{C}$ for 2,4 and $8 \mathrm{~h}$ display peaks similar to the raw char, but are more pronounced. A second large band is observable in Fig. 1 between 1000 and $1300 \mathrm{~cm}^{-1}$ which corresponds to the $\mathrm{C}-\mathrm{O}$ bonds of lactones, alcohol, phenol and ether (see Table 3). Thus FTIR spectra show that the different carbon-oxygen linkages have been increased after the $\mathrm{O}_{2}$ gas-phase treatment. However intensities of the different bands for the oxygenated chars are comparable and it is hard to conclude on the oxygenation time effect. Thus the TPD analysis has been used to provide more accurate understanding of the impact of the temperature and time of oxygenation on O-containing groups generated.

TPD is a dynamic analysis which consists of recording the production of $\mathrm{CO}_{2}$ and $\mathrm{CO}$ during the continual heating of the sample. Fig. 2 and Table 4 show the evolution and the total production of $\mathrm{CO}_{2}$ and $\mathrm{CO}$ over time for the raw and oxygenated chars at $280^{\circ} \mathrm{C}$ (obtained from the micro gas chromatograph analyses).

Table 3

FTIR peak assignments (adapted from [23]).

\begin{tabular}{lll}
$\begin{array}{l}\text { Related bands in } \\
\text { Fig. } 1\end{array}$ & $\begin{array}{l}\text { Wave number } \\
\left(\mathrm{cm}^{-1}\right)\end{array}$ & Functional group \\
\hline $\mathrm{C}=\mathrm{O}$ & $\begin{array}{l}1850-1786 \\
1740,1724\end{array}$ & $\begin{array}{l}\text { Anhydrides } \\
\text { Lactones }(\mathrm{C}=\mathrm{O})\end{array}$ \\
& $1710-1680$ & Carboxylic $(\mathrm{C}=\mathrm{O})$ \\
& $1670-1660$ & Quinone or conjugated keton \\
$\mathrm{C}-\mathrm{O}$ & 1440 & Carboxylic $(\mathrm{O}-\mathrm{H})$ \\
& 1264 & Lactones $(\mathrm{C}-\mathrm{O}-\mathrm{C})$ \\
& $1250-1235$ & Ether bridges between rings \\
& $1162-1114$ & Phenol $(\mathrm{C}-\mathrm{O})$ and $(\mathrm{O}-\mathrm{H}$ bend/ \\
& & stretching $)$ \\
& $1076-1014$ & Alcohol $(\mathrm{C}-\mathrm{O})$ \\
\hline
\end{tabular}

(a)

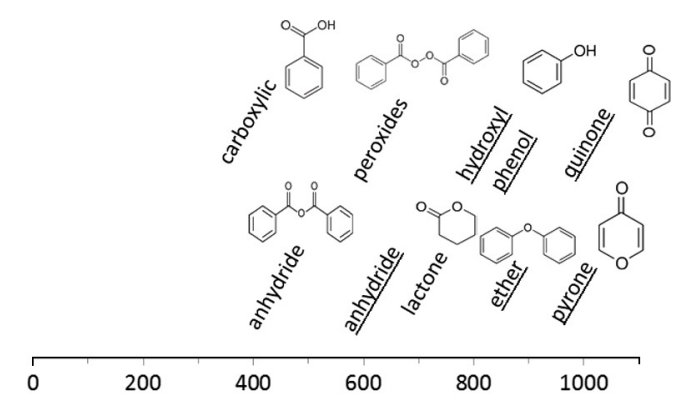

(b)

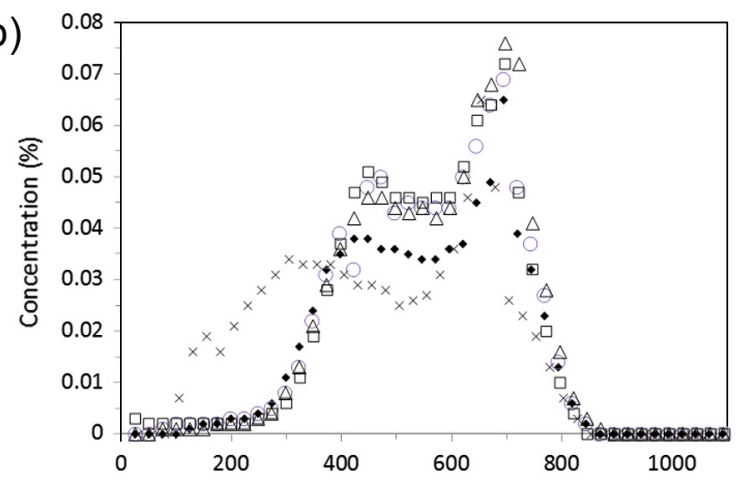

(c)

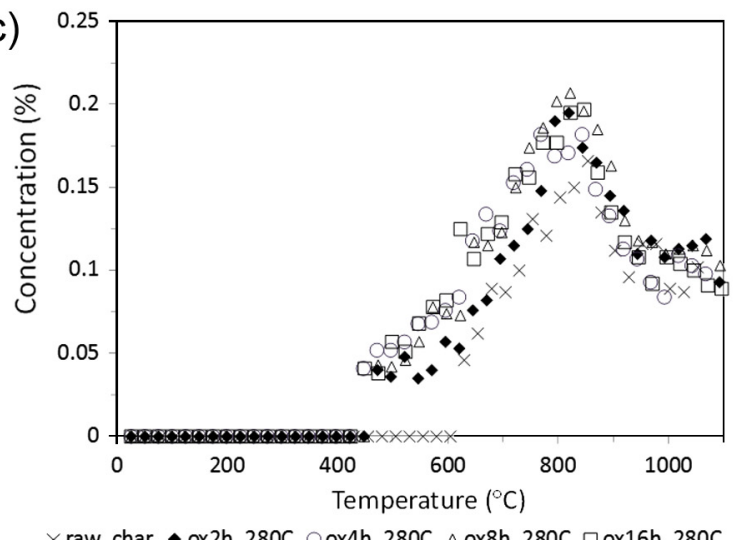

Fig. 2. An example of curve-fitting of the TPD curve with the TPRWin software from Quantachrome (char_ox_16h_280 ${ }^{\circ} \mathrm{C}$ ).

Table 4

Comparison of $\mathrm{CO}_{2}$, $\mathrm{CO}$ and total production for raw and functionalized chars oxygenated at $280^{\circ} \mathrm{C}$ for different duration times (from the integration of the area under the curve of Fig. 2).

\begin{tabular}{lllll}
\hline & $\mathrm{CO}_{2}$ & $\mathrm{CO}$ & Total & $\mathrm{CO}_{2} / \mathrm{CO}$ \\
\cline { 2 - 5 } & mmol/gchar & & & \\
\hline raw_char & 0.9 & 2.1 & 3.0 & 0.42 \\
ox_2 h & 0.8 & 3.0 & 3.9 & 0.28 \\
ox_4 h & 1.0 & 3.3 & 4.3 & 0.30 \\
ox_8 h & 1.0 & 3.5 & 4.5 & 0.29 \\
ox_16 h & 1.0 & 3.4 & 4.4 & 0.29 \\
\hline
\end{tabular}

On Fig. 2 one can observe that both the production of $\mathrm{CO}_{2}$ and $\mathrm{CO}$ increased between 400 and $800^{\circ} \mathrm{C}$ for the oxygenated chars. After $800^{\circ} \mathrm{C}$, the $\mathrm{CO}$ production is similar for all the samples and before $400{ }^{\circ} \mathrm{C}$ less $\mathrm{CO}_{2}$ is produced for the oxygenated chars which is explained by the loss of non-stable O-groups at that oxygenation temperature (this point is discussed more in detail in the selectivity part). The gases evolution over time is very interesting as well since we can observe that the curves of raw char and ox $2 \mathrm{~h}$ 
samples are well distinguished but the curves of ox_4 h, ox_8 $\mathrm{h}$ and ox_16 $\mathrm{h}$ are superimposed meaning that a saturation is reached. Koch et al. [23] has done a similar study on coal char and observed a saturation of the surface after an increase of the oxygenated functions as well.

Results of the integration of the area under the curves of the Fig. 2 highlighted that the $\mathrm{CO}_{2}$ and $\mathrm{CO}$ production were higher for the oxygenated chars than the raw chars (see Table 4). The total amount of oxygenated groups has been increased by a factor of 1.5 after $4 \mathrm{~h}$ of treatment since the raw_char sample contained $3.0 \mathrm{mmol} / \mathrm{g}_{\text {char }}$ and the ox $4 \mathrm{~h} \_280 \mathrm{C}$ sample $4.3 \mathrm{mmol} / \mathrm{g}_{\text {char }}$. Above $4 \mathrm{~h}$ of treatment the total amount of oxygenated functions remain almost stable. To conclude on the efficacy, the process has been successful and an increase of the total oxygenated functions was observable. However the total amount of O-groups must be regarded in terms of selectivity.

\subsubsection{Selectivity}

The next step is to evaluate the selectivity of the chemisorption with regard to the location of oxygen that was favored leading to the formation of some preferential groups. According to the literature, various types of oxygenated groups have been identified at the surface of the carbonaceous materials [24]. The theory of the TPD analyses is based on the distribution of desorption activation energies [25]. There is controversy in the literature over the assignment of the different peaks during TPD analyses. However some global trends have been established in previous studies [26-28]. $\mathrm{CO}_{2}$ desorption is mainly due to acidic functions such as carboxylic and anhydride acids, it could also come from lactone or peroxide. Its production is observed in the $100-800^{\circ} \mathrm{C}$ temperature range. Carboxylic acid desorption occurs at low temperature and lactone desorption at high temperature [27]. Carboxylic anhydrides produce both $\mathrm{CO}$ and $\mathrm{CO}_{2}$ and a small difference in the desorption temperature is observed. Peroxides should produce a $\mathrm{CO}_{2}$ peak at $550-600{ }^{\circ} \mathrm{C}$ [27]. CO which is produced above $600^{\circ} \mathrm{C}$ could originate from the desorption of weak acids such as phenol or hydroxyl but also from neutral or basic functions such as pyrone-like structure, quinone, carbonyl and ethers functions [20,25,29]. Hydroxyl and phenols desorb and produce $\mathrm{CO}$ in the $600-800^{\circ} \mathrm{C}$ temperature range and hydroxyl should desorb first. Pyrone-type structure and quinone (carbonyls) desorb at the highest temperature. In addition quinone desorb before pyrone-type structure. From the literature and the micro GC results, the signal has been deconvoluted using 13 Gaussians functions. The first one at $80^{\circ} \mathrm{C}$ has been assigned to water evaporation. The $\mathrm{CO}_{2}$ contribution was composed of 5 peaks: 1 for carboxylic acids at $390^{\circ} \mathrm{C}, 1$ for anhydrides at $450^{\circ} \mathrm{C}, 1$ for peroxides at $530^{\circ} \mathrm{C}$ and 2 for lactones at 660 and $720^{\circ} \mathrm{C}$. Six peaks have been attributed to $\mathrm{CO}$ production: 1 for anhydrides at $590^{\circ} \mathrm{C}, 1$ for hydroxyl at $620^{\circ} \mathrm{C}, 1$ for phenol at $750^{\circ} \mathrm{C}, 1$ for ether at $844^{\circ} \mathrm{C}, 1$ for quinone at $880^{\circ} \mathrm{C}$ and 1 for pyrone at $973{ }^{\circ} \mathrm{C}$. In addition a negative peak at $870{ }^{\circ} \mathrm{C}$ for $\mathrm{H}_{2}$ has been added. Peak temperatures (Tm) were bound by $\pm 50{ }^{\circ} \mathrm{C}$ and the Half Width at Half Maximum (HWHM) was kept constant. Fig. 3 presents an example of curve-fitting.

A first point of discussion is the evolution of the $\mathrm{CO}_{2} / \mathrm{CO}$ ratio over the process which is presented in Table 4. The initial $\mathrm{CO}_{2} / \mathrm{CO}$ ratio is of 0.42 for the raw biochar, after $2 \mathrm{~h}$ of treatment it decreases to 0.28 . This difference is due to the loss of a part of the carboxylic acids (production of $\mathrm{CO}_{2}$ ) during the heating ramp under pure nitrogen prior the oxygenation at $280^{\circ} \mathrm{C}$. During the oxygenation both functions producing $\mathrm{CO}_{2}$ and $\mathrm{CO}$ have been increased. Thus the ratio remains almost stable at $0.29( \pm 0.01)$.

Curves presented in Fig. 2 also show that the $\mathrm{CO}_{2}$ production for the raw-char sample starts near $100{ }^{\circ} \mathrm{C}$ whereas it begins closer to $300{ }^{\circ} \mathrm{C}$ for functionalized chars. Thus carboxylic acids desorbed during the heating ramp and were not formed during the oxygenation as the temperature was too high, the concentration of carboxylic acids has been decreased by a factor of four after the oxygenation process. Conversely peroxides and lactones have been increased 2.1 and 1.2 times respectively (see Fig. 2b). The anhydride groups desorbed in both $\mathrm{CO}_{2}$ and $\mathrm{CO}$ at $450{ }^{\circ} \mathrm{C}$ and $580^{\circ} \mathrm{C}$ respectively. Raw chars did not contain this type of function since the $\mathrm{CO}$ production started above $620^{\circ} \mathrm{C}$. However after oxygenation, Fig. 2 shows that the CO light-off temperature is lower for the functionalized samples compared to raw char indicating that anhydrides have been created.

On Fig. $2 \mathrm{C}$ it is observable that the shoulder near $700{ }^{\circ} \mathrm{C}$ increases suggesting that hydroxyl/phenolic groups are enhanced. Quinone and pyrone groups were apparently not impacted by the process. Results of the deconvolution show that hydroxyl, phenol and ether have been increased by a factor of 2.6, 1.7 and 1.3 respectively whereas quinones and pyrones concentrations have not been impacted. Therefore the oxygenation process seems to be selective. Figueiredo et al. [21] also concluded on oxygenation selectivity, especially CO-based functions, over commercial activated carbons (under a $5 \mathrm{v} \% \mathrm{O}_{2} / \mathrm{N}_{2}$ mixture at $425{ }^{\circ} \mathrm{C}$ ). With the extent of oxidation they also observed that the shoulder of the CO curve at low temperature became more predominant. They proposed an interpretation of this observation from the scheme described below proposed by Zhuang et al. [30]. This scheme presents the first possible interactions between oxygen, carbon atoms and oxygenated functions present at the surface. Secondary reactions or chain reactions such as Boudouard reaction or Water Gas shift reactions were not included in the following scheme:

$\mathrm{C}_{f}+\mathrm{O}_{2} \rightarrow$ carbonyls, ethers $(+\mathrm{CO})$

$\mathrm{C}_{f}+\mathrm{O}_{2} \rightarrow$ lactones, anhydrides

$\mathrm{C}_{f}+$ carbonyls, ethers $+\mathrm{O}_{2} \rightarrow \mathrm{CO}_{2}+\mathrm{CO}$ or carbonyls, ethers

$C_{f}+$ carbonyls, ethers $+\mathrm{O}_{2} \rightarrow$ lactones, anhydrides

lactones, anhydrides $\rightarrow \mathrm{CO}_{2}(+\mathrm{CO})+2 C_{f}$

carbonyl, ethers $\rightarrow \mathrm{CO}+\mathrm{C}_{f}$

\section{$C_{f}$ : carbon sites}

Phenol, ether, quinone and pyrone are the dominant functions on the raw biochar surface. Reactions (2) and (4) are not favored which explains that no increase of quinones and pyrone are observed. However reaction (5) where oxygen reacts with carbonyl and ethers already present at the surface to form lactones, anhydrides at higher extent seem to be the predominant reaction. Fanning et al. [31], also investigated oxidation of carbons under a mixture of $\mathrm{O}_{2} / \mathrm{Ar}$. They stated that oxidation by $\mathrm{O}_{2}$ gave evidence for initial formation of cyclic ethers. More complete oxidation produced cyclic anhydrides, lactones, phenols and ethers.

Fig. 4 shows that phenol, ether, quinone and pyrone are the main O-containing functions onto raw_char surface with percentages of $16 \%, 20 \%, 17 \%$ and $14 \%$. However after oxygenation only ether and phenol remain at $18 \%$ while quinone and pyrone contributions decreased to $12 \%$ because of the increase of hydroxyl, peroxides, lactones and the creation of anhydrides functions. Regarding anhydrides acids after $8 \mathrm{~h}$ of oxygenation they account for $12 \%$ of the total oxygenated functions whereas the raw biochars did not contain this type of function.

To conclude the oxygenation at $280^{\circ} \mathrm{C}$ mainly leads to increase the amount of oxygenated functions such as peroxides, lactones, hydroxyl and phenol which could be gathered into two main groups: the functions containing a $-\mathrm{OH}$ groups (hydroxyl and 


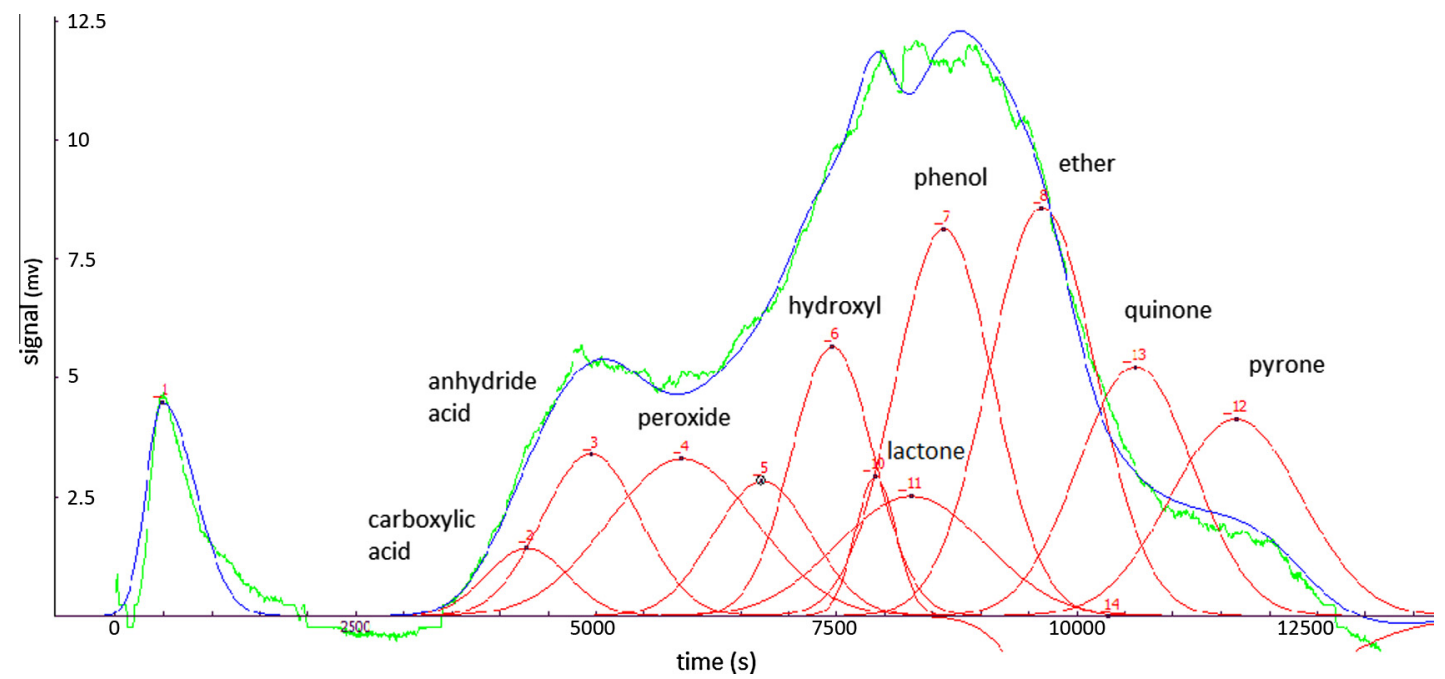

Fig. 3. Micro GC results during TPD of raw and functionalized chars oxygenated at $280^{\circ} \mathrm{C}$ for different times: (a) scheme of the temperature desorption of the $\mathrm{O}$-containing groups (in normal type face: groups producing $\mathrm{CO}_{2}$, underlined: groups producing $\mathrm{CO}$ ); (b) $\mathrm{CO}_{2}$ production; (c) $\mathrm{CO}$ production.

(a)
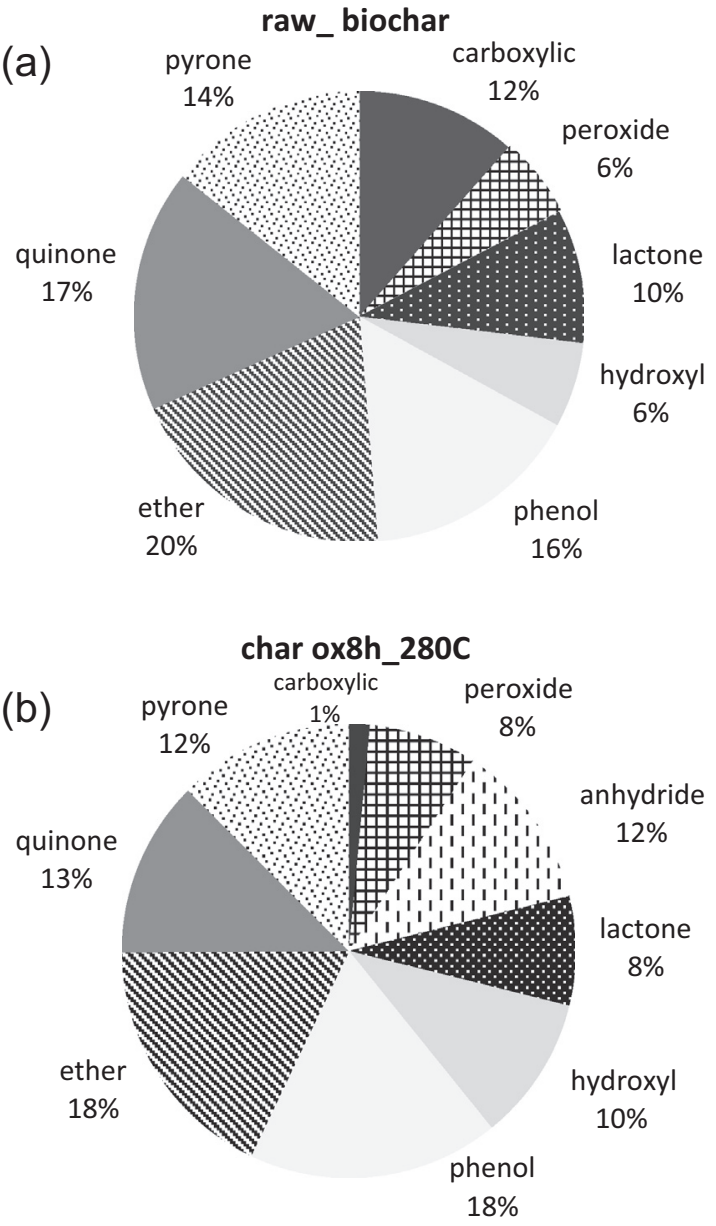

Fig. 4. Oxygenated groups distribution in atom\% of raw chars (a) and chars oxygenated $8 \mathrm{~h}$ at $280 \mathrm{C}(\mathrm{b})$.

phenol) and those composed of one (or more) atoms inserted into a carbon ring or carbon chain (peroxide, lactone). Anhydrides functions have been created as well and take part of the second categories of functions. This trend is coherent since the raw char surface was mainly covered by edge carbon functions such as
Table 5

Specific surface area, total micropore volume and mass loss of the raw and functionalized chars at $280{ }^{\circ} \mathrm{C}$ for different oxygenation times $(2 \mathrm{~h}, 4 \mathrm{~h}, 8 \mathrm{~h})$.

\begin{tabular}{llll}
\hline Sample & $S_{\text {BET }}\left(\mathrm{m}^{2} / \mathrm{g}\right)$ & $V_{\text {micro }}\left(\mathrm{cm}^{3} / \mathrm{g}\right)$ & Mass-loss \\
\hline raw_char & 573.8 & 0.219 & 0 \\
ox2h_280C & 530.5 & 0.216 & 7.1 \\
ox4h_280C & 475.1 & 0.207 & 11.1 \\
ox8h_280C & 464.1 & 0.204 & 11.6 \\
\hline
\end{tabular}

quinone and pyrone-like structures. Oxygenation at $280^{\circ} \mathrm{C}$ favored the formation of weak acid functions without removing basic groups such as quinone or pyrone. However the process reduce the amount of carboxylics, which are the strongest acids, by a factor of four. Thus the global amount of the oxygenated functions has been increased 1.5 keeping the duality of acidic and basic characters even if the new acidic functions at the functionalized biochars surface are less strong than the one of the raw chars.

\subsubsection{Global acidity}

The acidity of the surface is related to the oxygenated content and was investigated by measuring their $\mathrm{pH}_{\mathrm{pzc}}$. The $\mathrm{pH}$ of the raw chars and the functionalized chars are 3.1 and between 2 and 4 respectively. Literature reports the investigation of a correlation between the content of O-containing groups and the $\mathrm{pH}_{\mathrm{pzc}}$ [32-34]. A relationship has been established [22] and it shows that the $\mathrm{pH}_{\mathrm{pzc}}$ decreases rapidly as the oxygen content increases from 0 to $3 \mathrm{mmol} / \mathrm{g}$. Typically a $\mathrm{pH}_{\mathrm{pzc}}$ of about 9 corresponds to a low value of oxygenated groups $(1 \mathrm{mmol} / \mathrm{g})$. From $2 \mathrm{mmol} / \mathrm{g}$ of $\mathrm{O}$-containing groups at the carbon surface the value of $\mathrm{pH}_{\mathrm{pzc}}$ is under 4 and stabilizes between 3.5 and 2 for higher values of oxygen functions. Jaramillo et al. [35] studied different methods of oxygenation on activated carbons and observed the same trend. In this study the raw-char sample contains already $3.0 \mathrm{mmol} / \mathrm{gchar}$ and the content of the functionalized chars has been increased. The values of the $\mathrm{pH}_{\mathrm{pzc}}$ are stable in the 2-4 range which is coherent with the relationship established in the literature.

\subsubsection{BET specific surface area, porosity and mass loss}

Oxygenation at moderate temperature leads to two competitive reactions: combustion of a part of the biochars carbon structure appears while oxygen atoms adsorbed at the surface. This is 
confirmed by the mass loss which increases up to $4 \mathrm{~h}$ of treatment (see Table 5) and the production of $\mathrm{CO}_{2}$ and $\mathrm{CO}$ during the oxygenation process. These two reactions should have an opposite effect on the porosity. Combustion which burns carbon atoms from the surface should enhance the porosity by freeing the pores whereas chemisorption which leads to addition of oxygen atoms tends to fill the pores and decrease the specific surface area. BET analyses of the different biochars have been performed to statue which reaction has the predominant effect on the surface area and total microporosity. Table 5 provides BET surface area and micropore volume of the raw and functionalized chars. The raw char is a microporous material with a specific surface area of $573.8 \mathrm{~m}^{2} / \mathrm{g}$ and a micropore volume of $0.219 \mathrm{~cm}^{3} / \mathrm{g}$. At $280{ }^{\circ} \mathrm{C}$ all functionalized chars exhibit both smaller surface area and micropore volume than the raw_char sample. The specific surface area has been decreased by $20 \%$ after $4 \mathrm{~h}$ of treatment. Then chemisorption has been the predominant phenomenon and pores tend to have been filled. As the total oxygen amount and the surface area were determined for the different biochars, an estimation of the surface occupied by oxygen atoms at the biochars surface has been investigated. For the calculation, a value of $0.083 \mathrm{~nm}^{2}$ was assigned as the average area occupied by one oxygen atom chemisorbed on one carbon site on the primastic places of the surface [36,37]. The surface occupied by oxygen atoms at the raw_char surface has been evaluated to $159.2 \mathrm{~m}^{2} / \mathrm{g}$ which represents $27 \%$ of the BET surface area of the raw char. At saturation after $8 \mathrm{~h}$ of treatment the percentage of surface covered by oxygen is estimated at $51 \%$.

\subsubsection{Partial conclusion on the impact of the oxygenation times}

The oxygenation time played an important role since the longer the oxygenation, the higher the oxygen amount was chemisorbed until the saturation was reached. Oxygenation at $280^{\circ} \mathrm{C}$ above $4 \mathrm{~h}$ of oxygenation provides biochars containing 1.5 more oxygenated functions at their surface with both an acidic and basic character since the process increased weak acids such as anhydrides, peroxides and hydroxyl functions and did not remove basic groups. It has been observed that carboxylic amount was diminished by 4 after the treatment. Even if they are the strongest acids the global acidity of the surface remained unchanged since their loss was made up by the addition of the weak acids. Combustion during the $\mathrm{O}_{2}$ gas-phase treatment has been detected by the increase of the mass loss but it was not severe enough to counterbalance the oxygen chemisorption at the biochars surface. In fact the specific surface area has been decreased by $20 \%$. Thus we obtained good insights into evolution of the oxygenated functions arrangement over the process of oxygenation. Regarding the surface properties of the functionalized biochar the oxygenation at $280^{\circ} \mathrm{C}$ has been successful. The global amount of the oxygenated functions has been increased by $50 \%$ but the specific surface area was diminished by $20 \%$.

\subsection{Impact of the oxygenation temperature on the O-containing groups}

The temperature dependence of the oxygen chemisorption is the topic of this section. Temperature should increase the oxygen chemisorption thus higher oxygen content should adsorb at the surface. However combustion is sensitive to the temperature as well and could become the dominant reaction. Thus efficacy and selectivity of oxygen chemisorption on biochar surface is evaluated and discussed, especially as regards to the combustion reaction. The same approach as in 3.1 was developed to study the impact of the temperature on the oxygenated content, global acidity, porosity and mass loss of the chars.

\subsubsection{Efficacy}

FTIR applied to samples obtained after oxygenation at three temperatures demonstrated that the intensity of the bands corresponding to oxygenated functions increased (not shown). Therefore oxygenation was also successfully achieved. The amounts of $\mathrm{CO}$ and $\mathrm{CO}_{2}$ desorbed during TPD are presented in Table 6 (obtained from the integration of the area under the curve of Fig. 5). The total amount of $\mathrm{CO}$ and $\mathrm{CO}_{2}$ is 1.9 and 2.1 times higher after the oxygenation at 340 and $400{ }^{\circ} \mathrm{C}$ respectively. Temperature had a more significant impact on the oxygen chemisorption than the oxygenation times since the total amount was doubled in $2 \mathrm{~h}$ at $400^{\circ} \mathrm{C}$ and as recorded it was increased 1.5 times after $4 \mathrm{~h}$ at $280^{\circ} \mathrm{C}$. Although combustion reaction occurred at the same time TPD and FTIR results highlight that the oxygenated functions amount has been increased. The $\mathrm{CO}_{2} / \mathrm{CO}$ is also varying as the oxygenation temperature increases meaning that $\mathrm{O}$-functions are selectively increased.

\subsubsection{Selectivity and gobal acidity}

Fig. 5 shows a comparison of the $\mathrm{CO}_{2}$ and $\mathrm{CO}$ production of TPD analyses recorded by micro-GC when oxygenation temperature increases. $\mathrm{CO}_{2}$ and $\mathrm{CO}$ profiles at 340 and $400{ }^{\circ} \mathrm{C}$ are significantly higher than those of the raw_char and functionalized biochar at $280^{\circ} \mathrm{C}$.

As shown in Fig. 5, the $\mathrm{CO}_{2}$ production profile of the samples ox $2 \mathrm{~h} \_340 \mathrm{C}$ and ox $2 \mathrm{~h} \_400 \mathrm{C}$ are different from the raw_char. One large peak between 400 and $800^{\circ} \mathrm{C}$ is observable meaning that groups desorbing in this temperature range (anhydride, peroxide, lactone, hydroxyl and phenol) should have been significantly increased. In fact peroxides were enhanced 3.1 and 4.6 times at $340{ }^{\circ} \mathrm{C}$ and $400^{\circ} \mathrm{C}$ respectively. Regarding the lactone group, their amount has been enhanced by a factor of 1.6 and 2.0 at 340 and $400{ }^{\circ} \mathrm{C}$. Anhydrides have also been formed at these temperatures. They represent $11 \%$ and $10 \%$ of the total oxygenated functions for the samples ox $2 \mathrm{~h} \_340 \mathrm{C}$ and ox $2 \mathrm{~h} \_400{ }^{\circ} \mathrm{C}$ (see Fig. 6). Fig. 5.c highlights that hydroxyl and phenol have been significantly increased while ether, quinone and pyrone amounts remain stable. Results of the deconvolution show that hydroxyl amount was raised by a factor of 4 and 7 after oxidation at 340 and $400{ }^{\circ} \mathrm{C}$ respectively. The amount of phenol was nearly twice higher than the amount on the raw biochars after the two oxygenation processes. On the other hand carboxylic acids have been completely desorbed at these temperatures of oxygenation. Fig. 6 shows the distribution of the O-containing groups at the surface of sample ox $2 \mathrm{~h} \_340 \mathrm{C}$ and ox $2 \mathrm{~h} \_400 \mathrm{C}$. Predominant functions are phenol and hydroxyl with percentages of $24 \%, 20 \%$ and $17 \%, 21 \%$ respectively. Quinone and pyrone groups became the smaller percentages of the O-containing groups (9\%). Oxygenation at $340^{\circ} \mathrm{C}$ and $400{ }^{\circ} \mathrm{C}$ promotes the enhancement of weak acidic functions at the char surface without removing the basics groups. At $400{ }^{\circ} \mathrm{C}$, the $\mathrm{CO}_{2} / \mathrm{CO}$ ratio reaches 0.37 since the significant formation of peroxides, anhydrides and lactones balance the loss of carboxylic groups. Although the oxygenation increases slightly weak acidic functions, the $\mathrm{pH}_{\mathrm{pzc}}$ of the char oxygenated at 340 and $400{ }^{\circ} \mathrm{C}$ are of 2 and below 2 respectively. These results are coherent with the literature

\section{Table 6}

Comparison of $\mathrm{CO}_{2}$, $\mathrm{CO}$ and total production of raw_chars, ox $2 \mathrm{~h} \_280 \mathrm{C}$, ox $2 \mathrm{~h} \_340 \mathrm{C}$, ox $2 \mathrm{~h} \_400 \mathrm{C}$ obtained (from the integration of the area under the curve of Fig. 5).

\begin{tabular}{lllll}
\hline & tot $\mathrm{CO}_{2}$ & tot $\mathrm{CO}$ & tot & $\mathrm{CO}_{2} / \mathrm{CO}$ \\
\cline { 2 - 5 } & $\mathrm{mmol} / \mathrm{g}_{\text {char }}$ & & & - \\
\hline raw_char & 0.9 & 2.1 & 3.0 & 0.42 \\
ox2h_280C & 0.8 & 3.0 & 3.8 & 0.26 \\
ox2h_340C & 1.2 & 4.0 & 5.2 & 0.29 \\
ox2h_400C & 1.7 & 4.6 & 6.3 & 0.37 \\
\hline
\end{tabular}



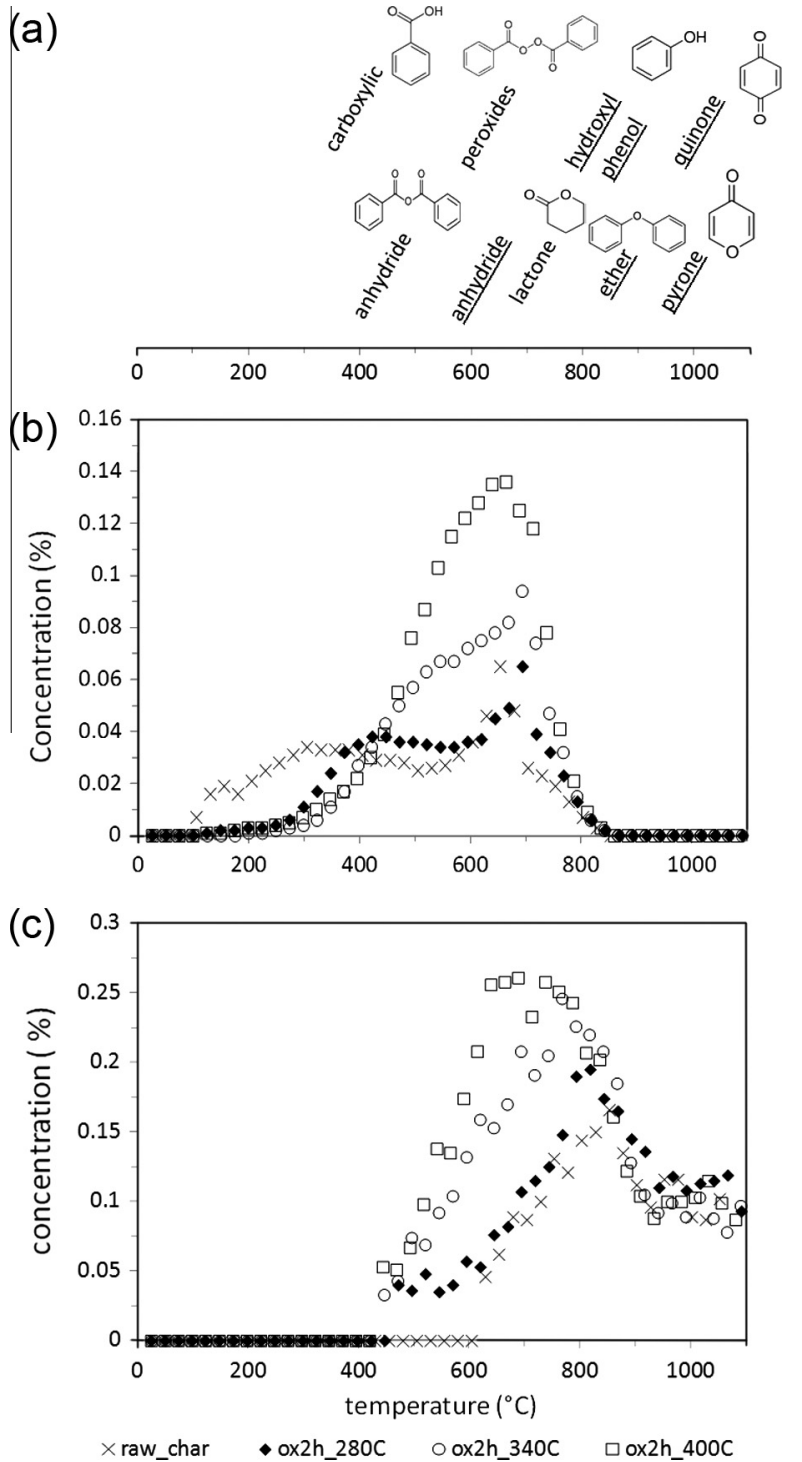

Fig. 5. Micro GC results during TPD of raw and functionalized chars oxygenated at $280^{\circ} \mathrm{C}, 340{ }^{\circ} \mathrm{C}$ and $400^{\circ} \mathrm{C}$ for $2 \mathrm{~h}$ : (a) scheme of the temperature desorption of the $\mathrm{O}$-containing groups (in normal type face: groups producing $\mathrm{CO}_{2}$, underlined: groups producing $\mathrm{CO}$ ); (b) $\mathrm{CO}_{2}$ production; (c) $\mathrm{CO}$ production.

and the discussion in the Section 3.1. The oxygen content of these two chars is higher compared to the one of the raw chars which has a $\mathrm{pH}_{\mathrm{pzc}}$ of 3.1. The high amount of oxygen function decreased the $\mathrm{pH}_{\mathrm{pzc}}$ of these chars.

\subsubsection{BET specific surface area, porosity and mass loss}

Table 7 shows the specific surface area, porosity and mass loss of the raw and functionalized chars. At 340 and $400{ }^{\circ} \mathrm{C}$, the oxygenation increased significantly the porosity and specific surface area. At $400{ }^{\circ} \mathrm{C}$, the porosity is enhanced by 1.5 while the specific surface area gained $15 \%$. The mass loss reaches $26.5 \%$ which is about 4 times higher than the one of the biochars oxygenated at $280^{\circ} \mathrm{C}$ for $2 \mathrm{~h}$. Thus combustion has been enhanced at higher temperature. Some oxygen atoms should have reacted with carbon atoms from the biochars surface. In fact $\mathrm{CO}_{2}$ and $\mathrm{CO}$ productions have been enhanced during the oxygenations at 340 and $400{ }^{\circ} \mathrm{C}$. Those operating conditions free the pores instead of filling them (oxygenation at $280^{\circ} \mathrm{C}$ ). The oxygenated biochars remain microporous.
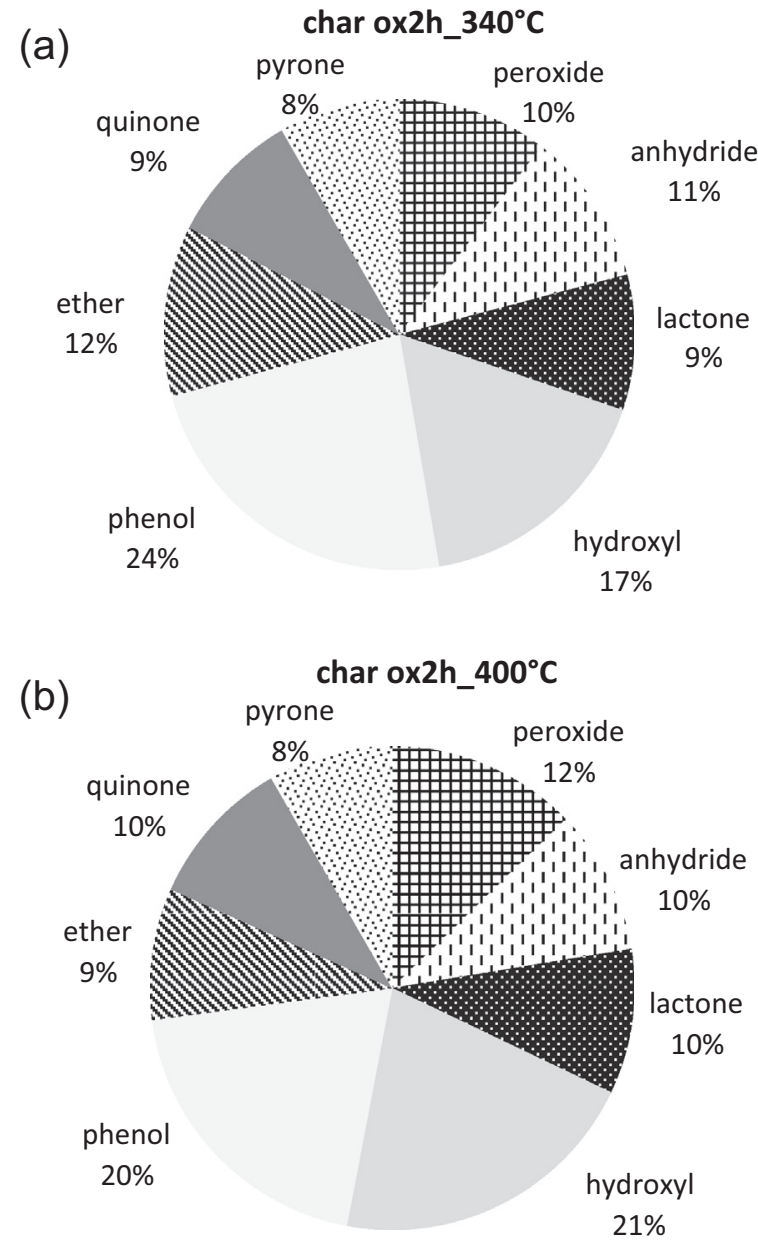

Fig. 6. Oxygenated groups distribution in atom\% of ox $2 \mathrm{~h} \_340 \mathrm{C}$ (a) and ox $2 \mathrm{~h} \_400 \mathrm{C}$ (b).

Table 7

Specific surface area, porosity and mass loss of the raw and functionalized chars oxygenated at 280,340 and $400{ }^{\circ} \mathrm{C}$ for $2 \mathrm{~h}$.

\begin{tabular}{llll}
\hline Sample & $S_{\text {BET }}\left(\mathrm{m}^{2} / \mathrm{g}\right)$ & $V_{\text {micro }}\left(\mathrm{cm}^{3} / \mathrm{g}\right)$ & Mass loss $(\%)$ \\
\hline raw_char & 573.8 & 0.219 & 0 \\
ox2h_280C & 530.5 & 0.216 & 7.1 \\
ox2h_340C & 627.1 & 0.301 & 12.2 \\
ox2h_400C & 666.8 & 0.323 & 26.5 \\
\hline
\end{tabular}

3.2.4. Partial conclusion on the impact of the oxygenation temperature

The oxygenation at 340 and $400{ }^{\circ} \mathrm{C}$ were more efficient rather than at $280^{\circ} \mathrm{C}$ since the total oxygen amount adsorbed on the biochar was increased 1.9 and 2.1 times respectively whereas it was increased 1.3 times after $2 \mathrm{~h}$ at $280^{\circ} \mathrm{C}$. Thus the oxygenation temperature plays a decisive role regarding the efficacy of the oxygenation. Hydroxyl, phenol, peroxides and lactones were the preferential functions enhanced, especially hydroxyl. The oxygen treatment was beneficial for the specific surface area and porosity. At $400{ }^{\circ} \mathrm{C}$, the porosity has been enhanced by 1.5 while the specific surface area gained $15 \%$. Literature highlights that carbon catalyst containing both acidic and basic O-containing groups are very interesting and competitive compared to commercial catalyst for the destruction of methyl tertiary butyl ether [11] or the $\mathrm{SO}_{x}$ and $\mathrm{NO}_{x}$ abatement [9]. In fact this kind of catalytic reactions are usually performed in a low temperature range (between 80 and 
$200{ }^{\circ} \mathrm{C}$ ) which is adapted for the utilization of the oxygenated biochars as catalyst since all the added oxygenated functions during the oxygenation process are stable up to $200^{\circ} \mathrm{C}$.

\section{Conclusion}

The oxygenation has been used to enhance the reactivity of gasification biochars. It has been shown that the oxygenation was successful over times (2-16 h) and operating temperatures $\left(280-400^{\circ} \mathrm{C}\right)$. However the higher the temperature was, the more efficient the oxygenation was. Whatever the conditions, the process is selective toward weak acids formation and the selectivity is enhanced at higher temperature. In addition, the combustion has a beneficial impact on porosity at high oxygenation temperature because it frees the pores. Indeed, at $400{ }^{\circ} \mathrm{C}$ the process leads to increase twice the total amount of oxygen atoms at the surface compared to raw biochar, while the increase is only of 1.3 at $280^{\circ} \mathrm{C}$. Oxygenation leads to an increase of selective O-groups. Especially, formations of weak acid functions containing a $-\mathrm{OH}$ groups (hydroxyl and phenol) and those composed of one (or more) atoms inserted into a carbon ring or carbon chains (lactone, anhydrides, peroxides) were favored since the raw biochars surface was mainly composed of $\mathrm{C}=\mathrm{O}$ functions (carbonyl, pyrone). Hydroxyl groups were particularly favored as the oxygenation temperature increased. After oxygenation biochars contain both acidic and basic functions. Porosity and specific surface area were enhanced significantly for the oxygenation reaction at 340 and $400{ }^{\circ} \mathrm{C}$. At $400^{\circ} \mathrm{C}$, the porosity has been enhanced by 1.5 while the specific surface area gained $15 \%$. Overall the results presented support the relevance of the oxygenation to increase the oxygenated groups at the surface of the biochars. This should lead to the increase of the reactivity for catalytic reactions presented in the introduction paragraph. Hence these catalytic reactions are performed at quite low temperature (below $200^{\circ} \mathrm{C}$ ). Added oxygenated functions at the biochars surface will be stable in this range of temperature.

\section{Acknowledgments}

This research was supported by the RAPSODEE Center at the Ecole des Mines d'Albi-Carmaux and the Earth Engineering Center at the City College of New York. The authors thank Sylvie Delconfetto, Séverine Patry and Jean-Marie Sabathier for assistance with experiments.

\section{References}

[1] Liu W-J, Zeng F-X, Jiang H, Zhang X-S. Preparation of high adsorption capacity bio-chars from waste biomass. Bioresour Technol 2011;102:8247-52. http:// dx.doi.org/10.1016/i.biortech.2011.06.014.

[2] Mohan D, Rajput S, Singh VK, Steele PH, Pittman CU. Modeling and evaluation of chromium remediation from water using low cost bio-char, a green adsorbent. J Hazard Mater 2011;188:319-33. http://dx.doi.org/10.1016/ j.jhazmat.2011.01.127.

[3] Rodriguez-Reinoso F. The role of carbon materials in heterogeneous catalysis*. Carbon N Y 1998;36:159-75.

[4] Sobana N, Swaminathan M. Combination effect of $\mathrm{ZnO}$ and activated carbon for solar assisted photocatalytic degradation of Direct Blue 53. Sol Energy Mater Sol Cells 2007;91:727-34. http://dx.doi.org/10.1016/i.solmat.2006.12.013.

[5] Barroso-Bogeat A, Alexandre-Franco M, Fernández-González C, Gómez-Serrano V. Preparation of activated carbon-metal oxide hybrid catalysts: textural characterization. Fuel Process Technol 2014;126:95-103. http://dx.doi.org/ 10.1016/i.fuproc.2014.04.022.

[6] Seredych M, Hulicova-Jurcakova D, Lu GQ Bandosz T]. Surface functional groups of carbons and the effects of their chemical character, density and accessibility to ions on electrochemical performance. Carbon $\mathrm{N} Y$ 2008;46:1475-88. http://dx.doi.org/10.1016/j.carbon.2008.06.027.

[7] Liu P, Liu W-J, Jiang H, Chen J-J, Li W-W, Yu H-Q. Modification of bio-char derived from fast pyrolysis of biomass and its application in removal of tetracycline from aqueous solution. Bioresour Technol 2012;121:235-40. http://dx.doi.org/10.1016/i.biortech.2012.06.085.
[8] Fujita S, Watanabe H, Katagiri A, Yoshida H, Arai M. Nitrogen and oxygendoped metal-free carbon catalysts for chemoselective transfer hydrogenation of nitrobenzene, styrene, and 3-nitrostyrene with hydrazine. J Mol Catal A Chem 2014;393:257-62. http://dx.doi.org/10.1016/j.molcata.2014.06.021.

[9] Teng $\mathrm{H}$, Tu Y, Lai Y, Lin C. Reduction of $\mathrm{NO}$ with $\mathrm{NH}_{3}$ over carbon catalysts The effects of treating carbon with $\mathrm{H}_{2} \mathrm{SO}_{4}$ and $\mathrm{HNO}_{3}$. Carbon N Y 2001;39:575-82.

[10] Szymanski GS, Rychlicki G, Terzyk AP. Catalytic conversion of ethanol on carbon catalysts. Carbon N Y 1994;32:265-71.

[11] Szymański GS. Catalytic destruction of methyl tertiary butyl ether (MTBE) using oxidized carbon. Catal Today 2008;137:460-5. http://dx.doi.org/ 10.1016/i.cattod.2008.01.003.

[12] Szymanski GS, Rychlicki G. Catalytic conversion of propan-2-ol on carbon catalysts. Carbon N Y 1993;31:247-57.

[13] Szymański GS, Rychlicki G. Importance of oxygen surface groups in catalytic dehydration and dehydrogenation of butan-2-ol promoted by carbon catalysts. Carbon N Y 1991;29:489-98. http://dx.doi.org/10.1016/0008-6223(91)90112-V.

[14] Pastrana-Martínez LM, Morales-Torres S, Likodimos V, Falaras P, Figueiredo JL, Faria JL, et al. Role of oxygen functionalities on the synthesis of photocatalytically active graphene- $\mathrm{TiO}_{2}$ composites. Appl Catal B Environ 2014;158-159:329-40. http://dx.doi.org/10.1016/i.apcatb.2014.04.024.

[15] Perrard A, Retailleau L, Berjoan R, Joly J-P. Liquid phase oxidation kinetics of an ex-cellulose activated carbon cloth by NaOCl. Carbon N Y 2012;50:2226-34. http://dx.doi.org/10.1016/j.carbon.2012.01.039.

[16] Klinghoffer NB, Castaldi MJ, Nzihou A. Catalyst properties and catalytic performance of char from biomass gasification. Ind Eng Chem Res 2012. http:// dx.doi.org/10.1021/ie3014082.

[17] Klinghoffer NB, Castaldi MJ, Nzihou A. Influence of char composition and inorganics on catalytic activity of char from biomass gasification. Fuel 2015. http://dx.doi.org/10.1021/ie3014082.

[18] El-Hendawy A-NA. Variation in the FTIR spectra of a biomass under impregnation carbonization and oxidation conditions. J Anal Appl Pyrolysis 2006;75:159-66. http://dx.doi.org/10.1016/i.jaap.2005.05.004).

[19] Xianglan Z, Shengfu D, Qiong L, Yan Z, Lei C. Surface functional groups and redox property of modified activated carbons. Min Sci Technol 2011;21:181-4. http://dx.doi.org/10.1016/i.mstc.2011.02.020.

[20] Otake Y, Jenkins RG. Characterization of oxygen-containing surface complexes created on a microporous carbon by air and nitric acid treatment. Carbon N Y 1993;31:109-21.

[21] Figueiredo JL, Pereira MFR, Freitas MMA, Orfao JJM. Modification of the surface chemistry of activated carbons. Carbon N Y 1999;37:1379-89.

[22] Lopez-Ramon MV, Stoeckli F, Moreno-Castilla C, Carrasco-Marin F. On the characterization of acidic and basic surface sites on carbons by various techniques. Carbon N Y 2000;37:1215-21.

[23] Kochan A, Krzton A, Finqueneisel G. A study of carbonaceous char oxidation in air by semi-quantitative FTIR spectroscopy. Fuel 1998;77:563-9.

[24] Figueiredo JL, Pereira MFR. The role of surface chemistry in catalysis with carbons. Catal Today 2010;150:2-7. http://dx.doi.org/10.1016/ j.cattod.2009.04.010.

[25] Zhang L-H, Calo J. Thermal desorption methods for porosity characterization of carbons and chars. Colloids Surf A Physicochem Eng Asp 2001;187188:207-18. http://dx.doi.org/10.1016/S0927-7757(01)00633-1.

[26] Karpinski Z, Szymanski GS. The effect of the gradual thermal decomposition of surface oxygen species on the chemical and catalytic properties of oxidized activated carbon. Carbon N Y 2002;40:2627-39.

[27] Zhou J-H, Sui Z-J, Zhu J, Li P, Chen D, Dai Y-C, et al. Characterization of surface oxygen complexes on carbon nanofibers by TPD, XPS and FT-IR. Carbon N Y 2007;45:785-96. http://dx.doi.org/10.1016/i.carbon.2006.11.019.

[28] Zielke U, Huttinger K, Hoffman W. Surface-oxidized carbon fibers:I. surface structure and chemistry. Carbon N Y 1996;34:983-98.

[29] Salame II, Bandosz TJ. Surface chemistry of activated carbons: combining the results of temperature-programmed desorption, boehm, and potentiometric titrations. J Colloid Interf Sci 2001;240:252-8. http://dx.doi.org/10.1006/ jcis.2001.7596.

[30] Zhuang Q, Kyotani T, Tomita A. DYNAMICS OF SURFACE OXYGEN COMPLEXES DURING CARBON GASIFICATION WITH OXYGEN. Energy Fuels 1995;9:630-4.

[31] Fanning PE, Vannice MA. A drift study of the formation of surface groups on carbon by oxidation. Carbon N Y 1991;31:721-30.

[32] Menendez JA. On the distribution of oxygen-containing surface groups in carbons and their influence on the preparation of carbon-supported molydenum catalysts. Solid State Ionics 1998;112:103-11.

[33] Borah D, Satokawa S, Kato S, Kojima T. Surface-modified carbon black for $\mathrm{As}(\mathrm{V})$ removal. J Colloid Interf Sci 2008;319:53-62. http://dx.doi.org/10.1016/ j.jcis.2007.11.019.

[34] Arenillas A, Pevida C, Rubiera F, Palacios JM, Navarrete R, Denoyel R, et al. Surface characterisation of synthetic coal chars made from model compounds. Carbon N Y 2004;42:1345-50. http://dx.doi.org/10.1016/i.carbon.2004.01.017.

[35] Jaramillo J, Álvarez PM, Gómez-Serrano V. Oxidation of activated carbon by dry and wet methods. Fuel Process Technol 2010;91:1768-75. http://dx.doi.org/ 10.1016/i.fuproc.2010.07.018

[36] Ismail IM, Walker P. Rates and heats of oxygen chemisorption on Saran chars at $100{ }^{\circ} \mathrm{C}$. J Colloid Interf Sci 1980;75:299-312. http://dx.doi.org/10.1016/ 0021-9797(80)90454-3.

[37] Vautard F, Dentzer J, Nardin M, Schultz J, Defoort B. Influence of surface defects on the tensile strength of carbon fibers. Appl Surf Sci 2014;322:185-93. http:// dx.doi.org/10.1016/j.apsusc.2014.10.066. 